\title{
ДО ПИТАННЯ \\ ПРО ПАСИВ ПЛЮСКВАМПЕРФЕКТА В УКРАЇНСЬКІЙ МОВІ ${ }^{1}$
}

\author{
ЛЮДМИЛА ПОПОВИЧ \\ Белградський університет, Белград - Сербія \\ ljudmilapopovic@yahoo.com \\ KWESTIA STRONY BIERNEJ CZASU ZAPRZESZŁEGO \\ (PLUSQUAMPERFECTUM) W JEZZYKU UKRAIŃSKIM \\ LUDMYŁA POPOWYCZ \\ Uniwersytet w Belgradzie, Belgrad — Serbia
}

\begin{abstract}
STRESZCZENIE. W artykule poruszono problem braku formy plusquamperfectum w stronie biernej języka ukraińskiego, przy jej występowaniu w stronie czynnej. Na konkretnych przykładach pokazano, że taksyjne i dyskursywne formy plusquamperfectum mogą być wyrażone przez bierną formę analityczną, zbieżną z formą strony biernej czasu przeszłego. Jeśli forma ta oznacza sytuację minioną, której efekty odbiegają od spodziewanego przebiegu zdarzeń, albo która została przerwana na skutek niespodziewanych okoliczności, to ma ona znaczenie plusquamperfectum, właściwe zarówno aktywnym, jak i pasywnym konstrukcjom czasownikowym języka ukraińskiego.
\end{abstract}

\section{ON THE PASSIV VOICE OF PLUPERFECT IN THE UKRAINIAN LANGUAGE \\ LJUDMILA POPOVIC \\ University of Belgrade, Belgrade — Serbia}

ABSTRACT. This paper focuses on the question of absence of the pluperfect in the paradigm of passive voice in the Ukrainian language, even though it is present in the active diathesis. The data show that taxis and discursive functions of pluperfect can be expressed by an analytic form of passive, which coincides with the past tense form of the passive voice. If such form represents a situation that develops in an unexpected way or is interrupted by another situation in the past, it represents the meaning of pluperfect, which is equally typical of both - the active and passive voice in the Ukrainian language.

$\Phi$ ункційна омонімія пасивних грамем. Граматичні категорії не існують ізольовано, а активно взаємодіють ${ }^{2}$, спричиняючи наявність чи відсутність відповідних грамем та форм у парадигмах тієї чи тієї категорії. Дієслівні категорії виду та стану визначають наявність часових форм: у дієслів доконаного виду в українській мові редукована парадигма часу, оскільки в ній відсутня грамема теперішнього часу, а парадигма пасиву, згідно з існуючими граматичними описами української мови, не містить давноминулого

1 Роботу виконано в рамках проекту 178021 за підтримки Міністерства науки, освіти та технологічного розвитку Республіки Сербії.

2 В. С. Храковский, Русский глагол: иерархия грамматических категорий, [в:] Љ. Поповић, Д. Војводић, М. Номаћи (ур.), У простору лингвистичке славистике. Поводом 65 година живота академика Предрага Пипера, Београд 2015, с. 777-798. 
часу або ж пасивний стан загалом розглядають поза часовими значеннями як результатив ${ }^{3}$.

Видові показники, зокрема, визначають наявність грамем пасивного стану. В українській мові аналітична форма 3 пасивним дієприкметником або предикативною формою на -но, -то прототипічно утворюється від дієслів доконаного виду (питання розглянуті / розглянуто), а пасивна форма дієслова формується від дієслів недоконаного виду (питання розглядається) ${ }^{4}$.

Таким чином, коли йдеться про взаємодію показників виду, стану та часу в українській мові, то вона виявляється в тому, що в дієслів доконаного виду активної діатези цілком логічно відсутня форма теперішнього часу 5 , а дієслівні лексеми пасивної діатези не мають часової форми плюсквамперфекта (ППФ). Така асиметрія темпоральних форм у активній та пасивній діатезах дає підставу задуматися над причиною відсутності ППФ у парадигмі українського пасиву. Звернення до інших слов'янських мов, у яких активно

${ }^{3}$ К. Г.Городенська Дієслово, [в:] I. Р.Вихованець, К.Г. Городенська, Теоретична морфологія украӥнської мови, Київ 2004, с. 243.

${ }^{4}$ Українські мовознавці останнім часом наполягають на вилученні дієслів недоконаного виду $з$ постфіксом -ся з парадигми пасивної діатези української мови (див.: К. Г. Городен с ь ка, зазнач. джер.). Таку думку, однак, спростовує мовна практика, яка показує, що конструкції $з$ дієсловами пасивного стану на -ся широко вживані в сучасній українській мові. Поділяємо думку тих науковців, які вважають, що граматика повинна реєструвати та категоризувати наявні в мові явища, а не наполягати на нормі, що протирічить мовній практиці (див.: А. М. Пе ш ко в с к и й, Объективная и нормативная точка зрения на язык, Москва 2010, с. 4). Відсутність дієслів недоконаного виду на -ся в парадигмі пасивної діатези додатково обмежує темпоральну зону пасиву в українській мові, оскільки унеможливлює вираження теперішнього актуального при трансформації семантичної ролі Пацієнса в роль Агенса, порівн.: Це питання досліджується науковиями (у даний момент, актуальний теперішній час).

Зачислення усіх пасивних конструкцій української мови до конструкцій 3 предикатами результативного стану (К. Г. Го роде н с ь ка, зазнач. джер., с. 243) теж не вважаємо доцільним, оскільки в усіх слов'янських мовах існують класи дієслів, від яких можна сформувати пасив тільки $з$ акціональним значенням (див.: В.С.Храковский, Пассивные конструкции, [в:] Теория функииональной грамматики. Персональность. Залоговость, СПб. 1991, с. 150). В українській мові це передусім дієслова зі значенням переміщення об'єкта: відвезти, привезти, надіслати, відіслати; передачі об’єкта: дати, продати, купити; соціального переміщення: призначити, перевести, звільнити, вислати; фазові: розпочати, продовжити, припинити; дієслова мовлення, розумової діяльності та сприйняття: промовити, проаналізувати, розглянути, помітити тощо. Утворені від таких дієслів пасивні дієприкметники не можна поєднувати 3 обставинами часу давно; все щее; щее не; вже; з ранку; до обіду; часто; рідко тощо, які можна вважати своєрідними аналітичними показниками результативного значення дієслівної форми (див.: В. П. Недялков, С. Е. Яхонтов, Типология результативных конструкций, [в:] Типология результативных конструкций (результатив, статив, пассив, перфект), отв. ред. В. П. Недя лков, Ленинград, с. 5-41).

${ }_{5}^{5}$ Припущення про наявність грамеми теперішнього часу в дієслів доконаного виду в східнослов'янських мовах (див. огляд цього питання у: А. П. З агн іт ко, Теоретична граматика сучасної української мови. Морфологія. Синтаксис, Донецьк 2011, с. 216) можна вважати дещо натягнутим, оскільки навіть у південнослов'янських мовах, де існує форма відповідної грамеми, іiї не можна референційно вжити на позначення одноразової реальної дії, за винятком автореференційних перформативних уживань теп. часу доконаного виду у словенській мові, де референтом дії стає саме висловлення, а не дія як така, порівн.: (словен.) Obljubim (док. вид теп. ч.), da bom izpolnjevala božje obljube (Обіцяю, що дотримуватимусь Божих заповідей). Відсутність форми теп. часу в дієслів док. виду є логічною, оскільки доконаний вид позначає нерозчленовану цілісну дію, що досягла певної межі, тоді як теперішній час позначає дію, що триває в момент мовлення. Несумісність цих сем і є причиною реальної відсутності теперішнього часу доконаного виду, навіть за умови наявності в мові відповідної форми. 
функціонує ППФ $\Phi^{6}$ зокрема до сербської ${ }^{7}$ може допомогти вирішити це питання.

В українській мові пасивні дієприкметники в предикативній функції та безособові предикативні форми входять до складу аналітичних утворень, що складаються 3 дієслова-зв'язки бути, представленого відповідними часовими формами (минулого, майбутнього часу та нульовою - теперішнього часу) i caмого дієприкметника: Лист \& надісланий вчасно; Лист був надісланий вчасно; Лист буде надісланий вчасно; Лист จ надіслано вчасно; Лист було надіслано вчасно; Лист буде надіслано вчасно тощо. Часові значення при цьому передає саме дієслово-зв'язка, оскільки дієприкметник належить до периферійних засобів вираження темпоральності ${ }^{8}$. Однак постає питання, чи дієслово-зв'язка здатне самостійно, без підтримки контексту, виразити часовий план? Якщо порівняти наведені часові грамеми пасивного стану в українській мові з відповідними в сербській, помічаємо, що сербські пасивні дієприкметникові форми теперішнього часу зі зв'язкою в теперішньому часі відповідають українським 3 нульовою зв' язкою: писмо је написано - лист $Q$ написаний. Виходячи 3 цього факту, сербські пасивні аналітичні форми з перфектом дієслова-зв' язки бити мають відповідати українським аналітичним утворенням зі зв'язкою бути в минулому часі: писмо је било написано - лист був написаний, оскільки перфекту сербського бити (био је) відповідає українська претеритальна форма був.

Пасивну грамему сербської мови, представлену аналітичною формою зі зв'язкою у формі перфекта био је одликован (був нагороджений), мовознавці традиційно відносять до форм пасивного ППФ9.

В останній нормативній граматиці сербської мови зазначено, що часові форми пасивного стану можуть збігатися, тобто одні й ті ж аналітичні форми можуть указувати на два часові плани залежно від контексту ${ }^{10}$. Згідно $з$ таким підходом пасив теперішнього часу (презенса) збігається з пасивом перфекта. Якщо дієслівна лексема в пасиві вказує на стан або постійну ознаку предмета, вона виражає часове значення презенса, порівн.: Bpama су отворена: PRS. PASS ${ }^{\prime l}$ (Двері відчинені); Стакло је премазано: PRS.PASS заштитним слојем (Скло вкрите захисним шаром). Коли ж ідеться про наслідок минулої події,

${ }^{6}$ Плюсквамперфект на сучасному етапі розвитку слов'янських мов послідовно збережено в усіх південнослов'янських: болгарській, македонській, сербській, хорватській, а з інших слов'янських - у верхньолужицькосербській та українській мовах. Спорадично можна зустріти цю часову форму в сучасній білоруській мові (див. дослідження цього питання в: А. Барен т сен, Наблюдение о встречаемости плюсквамперфекта в славянских языках, [в:] У простору лингвистичке славистике. Поводом 65 година живота академика Предрага Пипера, Љ. Попов ић, Д. Војв одић, М. Номаћи (ур.), Београд 2015, с. 135-160.).

7 Див. також на цю тему: Љ. Поповић, Функиије плусквамперфекта у савременом српском и украјинском језику, [в:] „Јужнословенски филолог” 2012, LXVIII, с. 113-145.

${ }^{8}$ А. В. Бон дар ко, Теория функииональной грамматики: Темпоральность. Модальность, Ленинград 1990, с. 44.

9 Див., напр.: К. Милошевић, Темпорално значење и синтаксичка вриједност конструкиија Cop (praes.perf.) + part.pass. у српскохрватском језику, [в:] „Јужнословенски филолог” 1973, XXX/1-2, с. 423-437; М. Ив и ћ, О значеюу српскохрватског плусквамперфекта, [в:] „Зборник за филологију и лингвистику” 1980, XXIII/1, с. 93-100; С. Танас ић, Синтакса глагола, [в:] П. Пи пер и др., Синтакса савременога српског језика, Проста реченииа, Београд 2005, с. 345-469; Љ. По по в и ћ, Контрастивна граматика украјинског и српског језика: таксис и евидениијалност, Београд 2014, с. 31-40; 44-47.

${ }^{10}$ П. Пипер, И. Клајн, Нормативна граматика српског језика, Нови Сад 2015, с. 189.

${ }^{11}$ Примітка. Тут та надалі використовуємо такі умовні скорочення: COND — умовний спосіб; COP — зв'язка; IPFV - недоконаний вид; PASS - пасив; PRF — перфект; PRS — презенс; PRET - претерит; PPRF — плюсквамперфект; PFV — доконаний вид. 
то його зачисляють до пасиву перфекта: Школа је отворена: PRF.PASS 1993. године (Школу відкрито в 1993 році). Зауважимо, що формально пасив в обох випадках збігається (складається зі зв'язки јесам у теп. часі та пасивного дієприкметника). Відмінним $є$ трактування форм, що залежить від профілювання, у випадку презенса, ознаки як стану тобто результату дії, з виведенням самої дії “поза кадр”, або, у випадку перфекта, саме дії, що призвела до наявного наслідку. Очевидно, що в цьому разі часове розмежування пасивних грамем засноване на розрізненні акціонального та результативного пасиву ${ }^{12}$, де результативний або статальний пасив віднесено до форм теперішнього часу, а акціональний - до форм минулого. Про такий підхід свідчить наявність у прикладі з пасивом перфекта обставини часу, що “прив'язує” наявний результат до часу виконання дії (1993. године). Така обставина, як зазначають дослідники відповідної проблематики, поєднується лише 3 акціональним пасивом $^{13}$.

Пасив перфекта, що складається з допоміжного дієслова бити в перфекті та пасивного дієприкметника, напр. био је саграђен (був побудований) може в сербській мові функційно збігатися 3 пасивом плюсквамперфекта ${ }^{14}$. Розмежування пасивного перфекта від ППФ теж засноване на функціях цих грамем. Якщо пасивом виражено актуальний у момент мовлення результат минулої дії, ідеться про перфект, а коли з контексту випливає, що після ситуації, вираженої пасивною грамемою, мала місце інша, яка звела нанівець результат попередньої, або ж ця грамема вказує на дію, започатковану в минулому, але з різних причин не здійснену, то таку форму розцінюють як ППФ, порівн.: Они субили осуђени: PRF.PASS на смрт (Вони були засуджені до страти); Они су били осуђени: PPRF. $P A S S$, а после рехабилитовани (Вони були засуджені, а потім реабілітовані) ${ }^{15}$. У першому прикладі аналітична форма били су осуђени (були засуджені) виражає значення перфекта, а в другому, — плюсквамперфекта.

Сербські мовознавці розглядають активні та пасивні грамеми або як паралельні часові форми, у яких замість дієприкметника активого стану на -л (PRF: назидао је, назидала је; PPRF: био је назидао, била је назидала) ужито пасивний (PRF.PASS: назидан је, назидана је, назидано је; PPRF.PASS: био је назидан, била је назидана, било је назидано $)^{16}$, або ж як форми, у яких часовий показник дієслова-зв' язки зсунуто "на один градус“" - презенсу зв' язки в складі грамеми активного стану відповідає перфект зв' язки в пасиві (Написала сам: COP.PRS писмо још јуче (Я написала листа ще вчора) - Писмо је било: COP.PRF написано још јуче (Лист написаний ще вчора). Такий часовий зсув дієслова-зв'язки призводить до збігу форм пасиву перфекта з ППФ, порівн. Писмо је било напи-

\footnotetext{
${ }^{12}$ Про акціональний та статальний пасив див.: В. С. Хр а ко в с ки й, указ. источ.

13 Про тести на розмежування акціональних від результативних значень аналітичних конструкцій з пасивними дієприкметниками див.: Ю. С. Маслов, Перфектность, [в:] А. В. Бондарко (ред.), Теория функциональной грамматики: введение, аспектуальность, временная локализованность, таксис, Ленинград 1987, с. 198-199; Ю. П. Княз ев, Конструкиия с русскими причастиями на -н, -m в семантической классификации предикатов, [в:] „Вопросы языкознания”, Москва 1989, № 6, с. 85; М. Ив и ћ, Српскохрватски глаголски облици за исказивање појава које постоје у садашъости, [в:] „Јужнословенски филолог” 1981, XXXVII, с. 20; Е. В. Падучева, Событийное и статальное значение глаголов совершенного вида в русском языке, [в:] Проблемы грамматики и типологии, сб. ст. памяти В. П. Недялкова, Москва 2010, с. 244 тощо.

${ }^{14}$ П. Пипер, И. Клајн, Нормативна граматика српског језика..., с. 407.

${ }^{15}$ Там само.

${ }^{16}$ М. С те в а н о в и ћ, Глаголски облици пасива, [в:] „Наш језик” 1956, VII / 7-10, с. 212.
} 
сано још јуче, али нисам стигла да га пошаљем (Лист був написаний ще вчора, але я не встигла його відіслати), де форма је било написано виражає значення не перфекта, як у попередньому прикладі, а ППФ, оскільки вказує на ситуацію, заплановану, започатковану, але не до кінця зреалізовану.

Подібний збіг спостерігаємо в сербській мові й між формами дієприкметникового пасиву імперфекта та ППФ зі зв' язкою у формі імперфекта, порівн.: Kyће беху зидане: IMP.PASS дуго (Будинки будувалися довго) ${ }^{17}$ з Куће беху зидане: PPRF.PASS, али се њихова градња никад није завршила (Будинки будувалися довго, але їхнє будівництво ніколи не завершено). У першому з прикладів аналітична форма пасиву зі зв'язкою в імперфекті (беху зидане) виражає часове значення імперфекта, а в другому - ППФ.

Таким чином, щоб установити відмінність між цими часовими формами в пасиві необхідна підтримка контексту — перфект, імперфект та ППФ виконують у пасиві притаманні їм функції. Оскільки формальні показники цих часових грамем у пасиві збігаються, то їх визначають саме за функціями.

Формальний збіг грамем ППФ з пасивними грамемами інших часових форм можна пояснити, виходячи з трактування цієї часової форми як відносної, якщо користуватися термінологією сербського мовознавця Александра Белича ${ }^{18}$, або ж співвіднесеністю референтної точки в семантиці цієї форми з подією в минулому, а не 3 часом мовлення, згідно 3 підходом Ганса Райхенбаха ${ }^{19}$, який, як відомо, розмежовував час повідомлення, час події та референтний час. При цьому референтний час можна розглядати як такий, у якому перебуває спостерігач.

Для перфекта та ППФ спільною є часова тяглість, тобто ці форми одночасно вказують на часові зони двох ситуацій — попередньої та наступної. Відмінність між ними полягає в тому, що часова зона ППФ жодним чином не перетинається 3 зоною часу мовлення: їх завжди розділяє часова зона іншої минулої ситуації. Якщо позиція спостерігача (референтний час) збігається із часовою зоною ситуації, що йде за іншою ситуацією, це так званий статальний перфект ${ }^{20}$ та статальний плюсквамперфект, що фокусують увагу на стані, до якого призвела попередня ситуація або безвідносно до неї. Перфект зосереджує увагу на стані в зоні теперішнього часу, а ППФ - на стані в минулому, що, як правило, перестає бути актуальним у момент мовлення. Якщо ж позиція спостерігача збігається з часом тієї ситуації, що передує іншій, має місце так званий акціональний перфект (loc.cit.) або акціональний ППФ, що профілює саму ситуацію в минулому, а не іiі результат. Іншими словами, акціональний перфект виражає в аналітичній формі пасиву подію, що призвела до результату, а статальний перфект - результативний стан ${ }^{21}$.

При визначенні функцій плюсквамперфекта важливо брати до уваги не лише позицію спостерігача, але й вектор його спостереження. Коли погляд спостерігача звернено в минуле, ідеться про ретроспективну референційність, при якій профілюється ситуація, що передувала іншій ситуації в минулому:

${ }^{17}$ Ж. Ст ан ојчић, Љ. Поповић, Граматика српскога језика, Београд 2000, с. 127.

${ }^{18}$ А. Бе л ић, О синтаксичком индикативу и ,, релативу”, [в:] Symbolae grammaticae in honorem Ioannis Rozwadowski II, Cracovia 1928, c. 47-55.

${ }^{19}$ H. Reichen b a ch, Elements of Symbolic Logic, Dover 1947.

${ }^{20}$ Ю. С. Ма с ло в, Избр. тр., Аспектология. Общее языкознание, Москва 2004, с. 54.

${ }^{21}$ Із цього аспекту необхідно розрізняти власне результативні конструкції, у яких наявний стан співвіднесено з результатом попередньої дії, напр.: борщ зварений, від стативних, де подано стан безвідносно до дії, напр.: місто оточене горами. Про розмежування результативних та стативних конструкцій див.: В. П. Недялков, С.Е.Яхонтов, указ. источ. 
3 того часу, 1883 року, украӥнській трупі були заборонили грати в усьому київському генерал-губернаторстві... I ия заборона лежсала тяжким гнітом на українськім театрі 10 літ (Микола Садовський, Мої театральні згадки). Якщо ж про попередню ситуацію повідомляють 3 синхронної позиції спостерігача, розташованого в часовій зоні минулого, то профілюється результат попередньої дії або ситуація, що поклала кінець розвитку попередньої ситуації: Вона була написала вчора листа, та випадково його витерла; Чапчик уже почав був обурюватись на літунів, але тут його перебив Супрун (Микола Хвильовий, Майбутні шахтарі).

У деяких слов'янських мовах, зокрема в болгарській та українській, форма ППФ допускає й третій випадок - проспективної перспективи, при якій спостерігач міститься в часовій зоні ситуації, вираженої ППФ, а його погляд звернено в майбутнє, тобто спостерігач умовно переноситься в час ситуації, після якої події розвиваються певним чином та моделює паралельний хід подій, який би міг мати місце, якби було здійснено інший вибір. Таке вживання ППФ як однієї з форм ірреалісу відоме в багатьох індоєвропейських мовах: воно отримало назву "модель біфуркації“22. В українській мові відповідне значення передається за допомогою умовного способу ППФ: Коли б був знав, проламав би запори та вкрав (Панас Мирний, Хіба ревуть воли, як ясла повні) 23 . Порівн. цей приклад з відповідним болгарським: Ако бях се отказал на време, нямаме да има неприятности (Якби був вчасно відмовився, не було б неприємностей) ${ }^{24}$.

Функції пасивних грамем ППФ. Прототипічною функцією ППФ можна вважати вираження результату минулої дії, анульованого іншою дією, а також позначення запланованої, але з різних причин не здійсненої ситуації в минулому. В обох випадках ППФ позначає ситуацію, що відхиляється від “умовної норми“", коли відсутнє звичне здійснення запрограмованої ситуації ${ }^{25}$.

Дослідники неодноразово звертали увагу на факт активного функціонування ППФ у сучасній українській мові ${ }^{26} .3$ іншого боку, до цієї розвідки науковці не задавалися питанням, чи існує в українській мові така часова форма в пасиві. Порівнюючи дані сербської мови з відповідними в українській, можна дійти висновку, що, подібно до того, як у сербській мові конструкція био је + пасивний дієприкметник може мати значення перфекта або ППФ залежно від кон-

${ }^{22} \mathrm{Ö} . \mathrm{D} \mathrm{h} 1$, The relation between past time reference and counterfactuality: a new look, [in:] A. A than asiadou, R. Dirven (eds.), On Conditionals Again, Amsterdam 1997, p. 97-114.

${ }^{23}$ На існування так званого контрфактичного ППФ в українській мові вперше було звернено увагу в роботі Л. Попо в ич, Граматичні та семантичні функиії плюсквамперфекта в сучасній українській мові, [в:] Акиентологія. Етимологія. Семантика. До 75-річчя акад. НАН України В. Г. Скляренка, Київ 2012, с. 653-673.

${ }^{24}$ Р. Н и ц о л в а, Българска граматика. Морфология, София 2008, с. 304.

${ }^{25}$ В.С.Храков ски й, Плюсквамперфект и конструкция с частищей было в восточнославянских языках, [в:] Ватрослав Ягич і проблеми слов'янознавства, Київ 2015, с. 295.

${ }^{26}$ Див.: А. П. Загнітко, Знову давноминулий? [в:] „Лінгвістичні студії”, зб. наук. праць ДоНУ, наук. ред. А. П. Загні тко, Донецьк 1996, № 2, с. 40-45; О.Кри жан ів сь ка, Спостереження за вживанням форм давноминулого часу в розмовно-побутовому мовленні, [в:] „Наук. зап. Вінниц. держ. пед. ун-ту ім. М. Коцюбинського. Сер. Філологія”, Вінниця 2001, № 3, с. 98-101; О. О. Таранен ко, Дієслово в контексті сучасних тендениій до перегляду нормативних засад української літературної мови, [в:] „Мовознавство” 2006, № 2-3, с. 55-77; Л. По п о в и ч, зазнач. джер.; Љ . По п о в и ћ, Контрастивна граматика украјинског и српског језика: таксис и евидениијалност...; Я. Мо вч а н, Плюсквамперфект в современных славянских языках: на примере болгарского и украинского языков, [in:] Trends in Slavic Studies, Москва 2015, p. 813827; Y. Movchan, Das Plusquamperfekt im Ukrainischen im Vergleich zum Bulgarischen, [в:] „Anzeiger für Slavische Philologie” 2014, XLI, c. 95-117. 
тексту ${ }^{27}$, українська форма, яка складається 3 дієслова-зв'язки бути в минулому часі та пасивного дієприкметника, може мати конкретне часове тлумачення залежно від конструкції, у якій іiі вжито. Таким чином, парадигма пасиву в українській мові може поповнитися ще однією часовою формою, що збігається 3 формою минулого часу. Конструкція, про яку йдеться, зокрема, може виражати значення ППФ, якщо вона виконує функції, притаманні цій часовій формі в українській мові, а саме:

- таксисну (позначення факту передування однієї ситуації іншій у минулому);

- вираження неактуального результату ситуації в минулому;

- вираження результату, анульованого іншою ситуацією;

— позначення започаткованої, але не завершеної ситуації;

- ретроспективної актуалізації;

- позначення дигресії;

— контрфактичну функцію ${ }^{28}$.

Залежно від контексту пасив форм минулого часу в українській мові в багатьох випадках насправді є пасивом ППФ, що підтверджує наявність перелічених функцій.

Плюсквамперфект (згідно з семантикою цієї часової форми) указує на передування в минулому однієї ситуації іншій. У пасивних конструкціях української мови цю функцію виконують дієприкметники з дієсловом-зв'язкою в минулому часі, що дає підставу розглядати такі аналітичні форми як пасивні грамеми ППФ, порівн.: Колишній офіцуер ВMC Украӥни [...] втік: PRET.PFV з міста, щзойно було розпочато: PPRF.PFV.PASS кримінальне провадження... („,Голос України”). У наведеному прикладі йдеться про таксис передування - спочатку розпочали кримінальне провадження, а потім офіцер утік. Така темпоральна орієнтація однієї ситуації в минулому відносно іншої належить до прототипічних прикладів уживання ППФ, що дає підставу розглядати аналітичну часову форму в даній конструкції саме як пасив ППФ. Порівн.: Щойно (були) розпочали кримінальне провадження, як офіцер [...] втік з міста. Численність конструкцій на позначення таксису передування однієї ситуації іншій з формами пасиву, які логічно можемо вважати пасивом ППФ, та відносна рідкість уживання в українській мові ППФ активної діатези на позначення цієї функції ${ }^{29}$ свідчить про те, що саме в пасиві український ППФ повністю зберігає свою відносну семантику. В активній діатезі часткове стирання значення відносного часу в семантиці ППФ призвело до розвитку в неї інших функцій, виокремлених вище.

Таксисні відношення в подібних конструкціях можуть бути фоном для інших, скажімо, причинно-наслідкових, у складнопідрядних реченнях 3 підрядним причини: Оскільки науковцем була закладена: PPRF.PFV.PASS саме така основа, ми продовжили: PRET.PFV дослідження в відповідному напрямку. У цьому прикладі (із так званим фоновим таксисом) темпоральна орієнтація ситуацій є лише фоном для інших, у цьому разі причинно-наслідкових ${ }^{30}$, передування однієї події іншій указує на наявність форми ППФ. Те, що ця форма збігається з пасивом минулого часу, не заперечує факту наявності пасивної грамеми ППФ в українській мові.

${ }^{27}$ П. Пипер, И. Клајн, Нормативна граматика српског језика..., с. 400-401.

${ }^{28}$ Функції ППФ в українській мові детально описані в одній з попередніх праць авторки на цю тему (див.: Л.По п о в и ч зазнач. джер.).

${ }^{29}$ Л. Попо вич, зазнач. джер.

${ }^{30}$ В. С. Храко в ский, Категория таксиса (общая характеристика), [в:] „Вопр. языкозн.”, Москва 2003, № 2, с. 37. 
До семантичного обсягу ППФ потрапляє минуле, що передує іншій ситуації в минулому, а це свідчить про актуалізацію референтної точки в минулому. Саме в ній знаходиться спостерігач, що повідомляє про минуле “другого ступеня". На механізмі такого перенесення спостерігача в минуле та актуалізації цього минулого засновано інші, нетаксисні, функції ППФ. Як було зазначено, між планом часу мовлення та планом минулого, вираженого ППФ, лежить часова зона, що не дає їм можливості перетнутися, тому для ППФ типовою $€$ сема дистанційності, яка реалізується незалежно від таксисної. На відтятості семантичної зони плюсквамперфекта від моменту мовлення заснована його функція позначення результату в минулому, що перестав бути актуальним у момент мовлення. Приклади підверджують, що таке значення можна виразити в українській мові не тільки формою активної діатези, але й пасивної, порівн.: 3 того часу, 1883 року, украйнській трупі були заборонили: PPRF. PFV грати в усьому київському генерал-губернаторстві... I ия заборона лежала тяжким гнітом на українськім театрі 10 літ (Микола Садовський, Мої театральні згадки) та Кажуть, що кіноповість О. Довженка “Украӥна в огні" була заборонена: PPRF. PFV.PASS особисто Сталіном.

Той факт, що часова зона ППФ не досягає до моменту мовлення, зумовлює ще одну його функцію - позначення ситуації в минулому, яку започатковано, але не доведено до кінця, оскільки ііі перервала інша ситуація. У типологічних дослідженнях ППФ така функція добре відома під назвою framepast $^{31}$. Значення перерваної ситуації типове для українського ППФ активної діатези. Найчастіше воно зустрічається в протиставних складносурядних реченнях, у яких форма ППФ розташована в першій частині речення, а в другій знаходиться дієслівна форма 3 відповідною семантикою зміни стану, порівн.: Я вчепився одною рукою в батькові штани, другою за шапку і хотів був: PPRF. IPFV сказати своє ім'я, та голосу не стало: PRET.PFV (Олександр Довженко, Зачарована Десна). Подібні до них конструкції пасивної діатези можна розцінювати як такі, у яких наявний пасив ППФ: Гігантоманія привела до того, що будівництво сотень об'єктів було розпочате PPRF. PFV. PASS, але не завершене через нестачу коштів, сировини, обладнання, робочої сили (http://histua.com/knigi). Порівн.: Будівництво сотень об'єктів були розпочали PPRF. PFV, але не завершили через нестачу коштів, сировини, обладнання, робочої сили.

Одним з типових уживань ППФ активної діатези в українській мові $є$ позначення нівельованого, дезактуалізованого результату минулої дії, порівн.: Шкільний курс валеології (науки про здоровий спосіб жсття) якось були запровадили: PPRF. PFV як експеримент, а потім від нього потихеньку відмовилися: PRET.PFV („Українська газета”). На значення зведеного нанівець іншою дією результату минулої ситуації може вказувати й ППФ пасивної діатези: Минулого місяия Дмитро Фірташ спочатку був арештований: PPRF.PFV.PASS у Biдні за запитом ФБР, а потім звільнений австрійським судом під заставу („Українська правда"). Результат ситуації в минулому може попри свою наявність не забезпечити їй успіху, тобто не прислужитися меті, із якою ситуацію було заплановано. Таку невдалість ситуації попри наявність результату, що мав би забезпечити іiі успіх, теж можна виразити в українській мові конструкцією пасивної діатези, що вказує на функційний ППФ. Порівн.: Як зміг крадій зайти до будинкy? Усі двері були позамикані: PPRF.PFV.PASS особисто мною. Ніде ні сліду злому замків.

${ }^{31}$ В. А. Плунгян, указ. источ. 
Плюсквамперфект недоконаного виду в українській мові фокусує увагу на ситуації, що подається з перспективи минулого: Швачка шарпонув правою рукою до кишені, а Кушнірів син, щзо стояв був: PPRF. IPFV під великим, висячим каганцем, погасив світло (Григорій Косинка, Політика). Таку ж функцію може виконувати й пасивний дієприкметник недоконаного виду 3 дієсловомзв' язкою в минулому часі, тобто така форма виконує відповідну функцію ППФ, але в пасиві, порівн.: Поклад у блоиі свердловини 5 було випробовувано: PPRF. IPFV.PASS при бурінні та у колоні (irbis-nbuv.gov.ua). Попри те, що безособова дієслівна форма на -но, -то недоконаного виду зазвичай указує на тривалу повторювану дію, дієслово-зв'язка минулого часу додає їй значення ретроспективної актуалізації, що входить до основних функцій ППФ в українській мові ${ }^{32}$.

Iз ретроспективною актуалізацією пов'язана і дискурсивна функція позначення нового тематичного блоку. Таку функцію ППФ може виконувати в українській мові як у складному, так і в простому реченнях, що розташовані на початку або в кінці абзацу, яким започатковано новий тематичний блок, тобто в зонах фокусування уваги читача ${ }^{33}$.

Ретроспекривна актуалізація, притаманна ППФ, складає підставу ще однієї функції цієї часової форми - дигресивної. У всіх мовах, у яких функціонує ППФ, його форми вказують не тільки на передування в минулому однієї ситуації іншій, але й на те, що ситуація, позначена ППФ, належить іншому часовому плану, відмінному від плану розповіді. Іншими словами, ППФ позначає „дискурсивно виділені дієслівні форми, що випадають з основної лінії розповіді"з3. Такий висновок підтверджують й українські приклади 3 пасивною діатезою, що свідчить про наявність у них дигресивної функції, типової для ППФ, порівн.: І тільки через дві години і по відльоті стає все зрозуміле. Точно через дві години, як було наказано: PPRF.PFV.PASS старому Йоганнові (Володимир Винниченко, Сонячна машина). Потрібно звернути увагу й на те, що в усіх наведених прикладах перед виділеною формою можна вставити прислівник попередньо, що підтверджує наявність семантичного ППФ, який за всіх перелічених умов зберігає відносність, притаманну цій часовій формі.

Контрфактична функція ППФ відноситься на припущення того, що певна ситуація, яка не відбулася, могла б мати місце в альтернативній дійсності, у якій події розвивалися б по-іншому. Мовознавці вважають, що сема темпорального дистанціювання від моменту мовлення, яка разом 3 таксисною функцією визначає характер плюсквамперфекта, може спричинитися до наявності в його семантичній будові семи епістемічної дистанції - коли плюсквамперфект на основі “дистанційної метафори” стає показником далекої від реальності ситуації, тобто вказує на її контрфактичність ${ }^{35}$.

Тоді як одні дослідники констатують, що сема часової віддаленості від моменту мовлення не обов'язково наявна в плюсквамперфектних формах, яким притаманна контрфактична функція, інші пропонують суттєво відмінні тлумачення цього явища. Пояснення механізму дії плюсквамперфекта в бага-

\footnotetext{
32 Див. Л. Поп о в и ч, зазнач. джер.

${ }^{33}$ В. Я рмак, Семантичний діапазон плюсквамперфекта в романі Драгослава Михаӥловича „Коли ивіли гарбузи” та в його перекладі українською мовою, [в:] Електронний ресурс: http://rastko.rs/rastko/delo/13698 (20.03.2017).

${ }^{34}$ В. А. Плунгян, О контрафактических значениях плюсквамперфекта, [в:] Y. А. L a nd e r, V. A. P lung i a n, A. Y. U rm a n c h i ev a (eds.), Irrealis and Irreality, Moscow 2004, p. 273-291.

${ }^{35} \mathrm{~S}$. F l e is chman, Temporal distance: a basic linguistic metaphor, [in:] „Studies in Language” 1989, No. 13 (1), p. 1-50.
} 
тьох мовах світу як показника ірреальності або гіпотетичності пов'язане 3 ідеєю ментальної операції перенесення в минуле, тобто в період, від якого відліковується певний хід подій: така модель відома в мовознавстві як "модель біфуркаціі”’36. За цією моделлю при вживанні плюсквамперфекта з контрфактичною функцією спостерігач умовно переноситься в минуле, ближче до референтної точки, після якої події розвивалися іншим ходом, що привів до наявного стану.

Обидва пояснення контрфактичної функції плюсквамперфекта (“дистанційної метафори” та “біфуркації”) детально розглядає В. Плунгян ${ }^{37}$, який пропонує нове вирішення цього питання, виходячи з притаманної цій часовій формі дигресивної функції, про яку йшлося вище: „По сути дела, контрафактическое условие описывает ту же самую дигрессию, только совершаемую не в реальном, а в воображаемом альтернативном мире" 38 . Така модель видається дуже логічною. Згідно з нею контрфактичність маніпулює моделюванням ситуації, що протиставляється реальній дійсності, і саме цей аспект семантичної будови плюсквамперфекта зумовлює наявність відповідної функції. Функція контрфактичності, коли ситуація моделюється як паралельна дійсність, незважаючи на реальні знання про те, що іiї не існувало, притаманна і українському плюсквамперфектові, коли він уживається в складнопідрядному реченні з підрядним умови: Якби була знала: PPRF.IPFV.COND/ У колисці б задушила: COND./ Під серием приспала (Тарас Шевченко, Розрита могила). Рідше контрфактичний плюсквамперфект зустрічаєься в обох частинах складнопідрядного речення - підрядному умови та головному: Якби була-м знала: PPRF. IPFV. COND, була б не кохала: PPRF. IPFV.COND $і$ з тобою до півночі не стояла б: $P P R F$. IPFV.COND. Контрфактичність наслідку в останньому прикаді виражена плюсквамперфектом у формі умовного способу (була б не кохала), тобто ситуація, що відбулася в дійсності, заперечується при іншому розкладі подій.

Контрфактичність в українській мові можна виразити і в конструкціях пасивної діатези, переважно в підрядній частині з'ясувального складнопідрядного речення, після модальних дієслів волевиявлення. Порівн.: Завдання було б виконане: PPRF.PFV.COND.PASS учнем, якби він вивчив урок. У наведеному уривку вжито пасивну конструкцію контрфактичного ППФ, що співвідноситься 3 відповідною конструкцією з ППФ активної діатези, порівн.: Учень був би виконав: PPRF.PFV.COND завдання, якби він вивчив урок. Звернімо увагу, що в разі заміни форми ППФ формою минулого часу в останньому прикладі втрачаємо значення ірреальної минулої умови (учень міг виконати завдання, та не виконав), яка при такому часовому зсуві стає потенційною: Учень виконав би: COND завдання, якби він вивчив урок (учень може виконати завдання за певної умови). Розмежувати потенційну умови від ірреальної минулої в українській мові дає можливість саме часова форма ППФ, і цю функцію, як бачимо, вона виконує як в активній, так і в пасивній діатезі.

Висновок. Як показує дослідження, український плюсквамперфект належить до типу плюквамперфекта з розширеними функціями, які ця часова форма може виконувати в конструкціях активної та пасивної діатези. Форми вираження пасивного ППФ в українській мові збігаються з формами пасиву минулого часу. Такий збіг форм пасивної діатези не $є$ винятком. Подібну омонімію

\footnotetext{
${ }^{36} \mathrm{Ö}$. Dah1, ibidem.

${ }^{37}$ В.А.Плунгян, указ. источ.

${ }^{38}$ Там же, с. 286.
} 
часових форм у пасиві спостерігаємо і в інших мовах, зокрема в сучасній сербській. Подібно до того, як розмежування перфекта від плюсквамперфекта або плюсквамперфекта від імперфекта в пасивних конструкціях сербської мови стає можливим на підставі контексту, у якому чітко виявляють себе функції, притаманні цим часовим формам, підставою для виокремлення пасиву ППФ в українській мові мають бути функції, які ця часова форма виконує в конструкціях активної діатези. Завдяки такому підходу, часову парадигму пасиву в українській мові логічно поповнено формою, що співвідноситься 3 відповідною формою активної діатези. Приклади підтверджують, що саме в пасивних конструкціях української мови ППФ активно вказує на передування однієї ситуації іншій. Часткове згортання таксисної функції плюсквамперфекта в конструкціях активної діатези в українській мові призвело до розвитку в його семантиці інших показників, що спричинили появу інших функцій. Нові функції забезпечують формам українського плюсквамперфекта активну вживаність у сучасній мові. 